\title{
The Implication of Freedom of Expression for Teenagers on Social Media in Indonesia
}

\author{
Harisa Mardiana ${ }^{1}$, Devi Hellystia ${ }^{2}$, Muhammad Ali Ghufron ${ }^{3}$ \\ Fakultas SainsdanTeknologi, Universitas Buddhi Dharma, Tangerang, Indonesia ${ }^{1}$ \\ Faculty of Humanities, Universitas Buddhi Dharma, Tangerang, Indonesia ${ }^{2}$ \\ Faculty of Language and Art, Universitas Indraprasta, Indonesia ${ }^{3}$ \\ \{harisa.mardiana@ubd.ac.id ${ }^{1}, \underline{\text { devi hellystia@staff.gunadarma.ac.id }}{ }^{2}$, \\ maghufron@gmail.com ${ }^{3}$ \}
}

\begin{abstract}
The author interest to do this research to investigate the implication of freedom of expression for teenagers on social media in Indonesia. In term of freedom of expression is to express a positive expression on social media. Many teenagers use social media, and sometimes they have trouble in expressing their expression, and it will be a mockery and insulted. Thus, they are overwhelmed and stressed. This research discusses the issue of freedom of expression that can be instilled correctly in teenagers. There is 87 respondent which is distributed via questionnaire in Google Form between April and May 2018. This research uses the quantitative method, descriptive analysis, observation, and semi-structured qualitative method. The result of this research found that teenagers understand about freedom of expression and they can implement on social media. Freedom of expression is very important to be known and understood by teenagers in the real world and in cyberspace. Moreover, this research is proved that teenagers understand the freedom of expression on social media in Indonesia.
\end{abstract}

Keywords: Freedom of expression, teenagers expressing, social media, the implication of freedom of expression on social media

\section{Introduction}

Social media develops to contribute to the process of spreading the idea of symbolization, and the way people see things. Media coverage is a form of representation of the reality of everyday life that has been constructed through signs or symbols. Wijaya (2015) stated that the most widely used by teenagers is Facebook and followed by Twitter, Google +, Linked, Instagram, Skype, and Pinterest. Thakurta, P.G (2012) indicated that social media combines technology, telecommunications, and social interaction so that it can be stated that social media provides a platform for communicating through words, images, films, and music that can exchange content by its users. And Kaplan. A and Haelein. M (2010) defined social media as a group of internet-based applications that build on the ideological and technological foundations of Web 2.0 and allow the creation and exchange of user-generated content. [1]. In term of understanding freedom of expression can be understood that every idea of a person has the natural right to freedom of expression without absolute and carry out its duties and responsibilities and have special restrictions set by law [2]. There are many Indonesian people 
are addicted to social media especially for teenagers. Indonesia teenagers have used smartphone almost 24 hours to find out what happens to their visual world. This is because social media offers the easier way to find out about everything and the teenagers seem to be comfortable to use it [3]. And the problem arises that many Indonesian teenagers have been abused, sexually assaulted and bullied in social media because of the lack of information technology knowledge in using social media together with the supervise from the parents or adults [4]. A story from Tempo.co, Wednesday, January 2, 2013; that mother reported to the police that the daughter (13 years old) had been bullied. As a matter of fact, her daughter was a very shy, quiet child. One day, she confirmed a friend from school on Facebook, and since that time, she had been bullied from her friends. She would be bullied at school, and come home and $\log$ on to the laptop and continued to be bullied. She would escape. And she very regrets to confirm school friend on Facebook. In fact, social media has been misused by teenagers, especially with the teenagers around 13 years old. In fact, social media have been published the rules since it is activated. Facebook, Twitter, Snapchat, Google +, Line, WhatsApp, Youtube are already announced that 13 years and under are not allowed to use social media. And the minimum age of using social media is 18 years old. It is quite clear [5]. This is because of lack of supervision and control from parents, teachers or adults surrounding her [6]; [4]. At the previous research by Gayatri, et.al (2015) informed that some children and teenagers are interested in searching on the Internet and present themselves on photo profile construction, visual and textual self-presentation which considered untruthfulness, vulgar. Kapan and Haenlien,(2010) mentioned that on the basis of ideology and web 2.0 technology, social media is built that allows the creation and exchange of content created by the user. When they post the good one, it will impress others, but they will post others to make invisible people happy. Based on the previous researchers, the author concluded that freedom of expression on social media has a consequence of human potential to think and to possess freedom of expression. The ability to determine themselves to have more positive existence on social media. And the researcher is interested in investigating freedom of expression for teenagers on social media and to minimize the gap of freedom of expression on teenagers in using social media with giving them the knowledge and a set of example about freedom of expression.

\section{Literature review}

Social media is a big part for many teenagers which has risks and benefit. By telling the teenagers and children on some of the social media rules, parents, teachers, and adults can help them the framework of social media [5]. Social media is a platform for freedom of expression if you can access the internet and you can create an account. It allows expressing own opinion through tweets, status updates, and photos. Considering to be a basic human right, freedom of expression will fulfill the human right through its accessibility [7].

The aspect of freedom of expression integrates with freedom of information, where the public has the right to access information that is held by public authorities and applied to social media [8]. In another article, Hamid.U.,(2015) highlighted that social media opens the space to express the views even though it is against each other, but the government has rules and regulations of dissent expression through the traditional and non-traditional form. Freedom of expression on social media means to respect, to value the opinion of all people through the internet. The article that was written by Townsend \& Wallace, (2010) stated that to express one's own opinions on social media platforms is not allowed to express gestures as an inseparable tool when explaining opinions and to ensure praise of emotional intentions in 
an argument. Teenagers have a new way to socialize without meeting face to face in person. When words are written in the text, can be interpreted as emotions from the teenager which can sometimes be a sensitive expression problem when speaking face to face. Social media cannot help to prevent people from talking with a free mind; this can be interpreted as skewed interpretation [9]. They may stir passion, and these words can influence the perception of others. This is a norm for teenagers including adults, who have been socialized in the new environment. They experienced and formed relationships the social activities online on social media where they are expected to be involved in sharing information with others (pp.59). Many perceptions in a sentence on a topic that causes a backlash from someone else. For example, when someone tries to write a sensitive subject with online empathy, without showing serious facial expressions, many comments from other people are different or skewed. And the responses that skewed are given a "thumb warrior." [10]. Many statements agree or disagree with one's status to voice controversial topics on social media platforms.

\section{Methods}

\subsection{Method of Research}

This quantitative research is to determine the impact of freedom of expression for teenagers on social media in Indonesia based on the basic understanding of freedom of expression and the ability to express themselves on social media. There is 87 subject sampling selection which has been spread out through Facebook. Data collection techniques regarding to qualitative were collected from teenagers to be interviewed for 2-3 hours in May and June 2018. Data research is taken from the literature review and questionnaires which had been developed by the authors. Semi-structure interviews were conducted with the author.

\subsection{Research Material}

The questionnaires for the research was created and deployed to finding the use of freedom of expression for teenagers on social media in Indonesia. The questions were developed to measure respondents' use of social media in Indonesia. For the research, an extensive exploratory phase was conducted in order to better ascertain that issue of the importance of freedom of expression for teenagers on social media in Indonesia. And the questions were divided into:

1. The Understanding of Freedom of Expression for Teenagers (Q)

2. The Use of Social Media for Teenagers in Indonesia (S)

3. Freedom of Expression on Social Media (QS)

\subsection{Research Procedure}

Lickert-scale was used in this research. The items for questionnaires are divided into 2 dimensions of questions about freedom of expression for teenagers on social media in Indonesia. The questionnaires are used to the questions from [1] strongly disagree, [2] disagree, [3] agree, and [4] strongly agree. Respondents for this research are $100 \%(n=87)$. The interview was given to 8 lecturers regarding freedom of expression for teenagers on social media in Indonesia. 


\subsection{Variables and Hypothesis}

This section is a brief explanation before the study an extensive exploratory phase was explained in order to accomplish the hypothesis. The study research issues of importance to check two variables to divide in the hypothesis.

The hypothesis of the research:

1. Teenagers understand to use freedom of expression to express themselves (Q)

2. Teenagers know how to use social media (S)

3. The relationships between freedom of expression for teenagers on social media which are located in Indonesia (QS)

\section{Result and discussions}

\subsection{Finding and Result}

From the questionnaires, they were found that the frequencies and percent values of the implication of freedom of expression for teenagers on social media were analyzed and from the questionnaires about teenagers understand freedom of expression on social media, which is the way to use freedom of expression on social media by teenagers in Indonesia. The research is indicated that the value of research using SPSS vs. 16.

The first step is to measure the correlation between the understanding of teenagers about freedom of expression and the way that the teenagers of using social media.

Table 1. Descriptive statistic of Correlation for each variable $(\mathrm{N}=87)$

\begin{tabular}{ccccc}
\hline Variables & \multicolumn{3}{c}{ Correlation } & \multirow{2}{*}{$\begin{array}{c}\text { Reliability } \\
(\alpha)\end{array}$} \\
\cline { 2 - 4 } & $\mathbf{Q}$ & $\mathbf{S}$ & QS & $\mathbf{0 . 7 3 2}$ \\
\hline $\mathrm{Q}$ & $\mathbf{0 . 9 4 2 * *}$ & & & $\mathbf{0 . 7 3 5}$ \\
\hline $\mathrm{S}$ & $\mathbf{0 . 7 1 9 * *}$ & $\mathbf{0 . 9 1 1 * *}$ & & $\mathbf{0 . 9 0 5}$ \\
\hline $\mathrm{QS}$ & & & $\mathbf{1}$ & \\
\hline
\end{tabular}

** Correlation is significant at the 0.01 level (2-tailed)

Q: Teenagers understand freedom of expression to express themselves

S: Teenagers know to use social media including the rules and regulations

QS: The Implication of freedom of expression for teenagers on social media

From the data above, Q represents for the teenagers understand about freedom of expression which they know to express themselves with a lot of control and supervise from the parents, teachers, and adults surrounding them. The reliability $(\alpha)$ of $Q$ is 0.732 . The strong reliability is shown that teenagers are consistent in answering the questions related to each of the questions on the questionnaires. The correlation $\mathrm{Q}$ has strong significant. It is shown that the $p$-value is $0.942 \geq 0.01$. It is indicated that the teenagers understand each question on the questionnaires. Freedom of expression is understood before they express themselves either offline or online. Granger \&Salat (2016) found out that freedom of expression is an important to the human right for a democratic society and it enables the free exchange of ideas, opinion, and information and allows the member of society to form their own opinion on the issue of public importance. Thomas Scanlon (1972) defined that everyone including teenagers has a right to communicate his or her opinion and ideas and share information in any form as long 
as they do not hurt someone else. Therefore, the variables about freedom of expression for teenagers is accepted.

$\mathrm{S}$ is represented as the use of social media for teenagers including the understanding of the rules and regulation of social media. The reliability $(\alpha)$ of $S$ is 0.735 . The strong reliability is shown the teenagers understand how to use social media and the teenagers agree on have some good qualities of questions. The correlation of S has a strong significant correlation between each question on the questionnaires. It is shown that the p-value is $0.911 \geq 0.01$ represents of teenager understand how to use social media including the rules and regulations. Madden et al., (2013) indicated that teenagers share information about themselves on social media site, which is social media is designed to encourage the sharing information and to embrace themselves publicly, but also they take an array step to restrict and prune their profile. Rideout (2012) stated that most teenagers feel that social media helps them on balance in rather than hurt their relationships (54\%), and nine out of ten teenagers $(88 \%)$ said that social networking has helped them keep in touch with friends that they cannot see regularly. 57\% stated that it had connected the with new people with whom they share a common thought or interest or hobby. But Ellen Niemer (2010) indicated that around 10\% of social media has bad effect on teenagers. Some of the teenagers have the signs of certain psychiatric disorders such as narcissism and show of depression which makes people feel uncomfortable. Thus, the variables about the teenagers know to use social media including the rules and regulation is accepted.

QS Represents of correlation of Q and S that is about the impact of freedom of expression on social media. The reliability $(\alpha)$ if QS is 0.905 and it indicates that the correlation of $Q$ and $\mathrm{S}$ is very strong and very significant. The correlation of QS is perfect; it is shown that the $\mathrm{p}$ value is $1>0.01$. Both QS has perfect relationships which implied to the teenagers when they express themselves on social media. The freedom of expression is understood by them. Both correlations of $\mathrm{Q}$ and $\mathrm{S}$ showed positive one-way value. The correlation between $\mathrm{Q}$ and $\mathrm{S}$ is shown in Scatterplot.

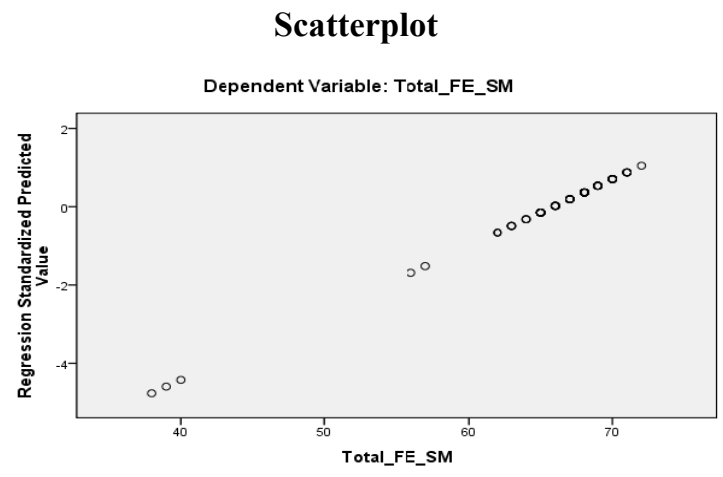

Correlation of $\mathrm{Q}$ and $\mathrm{S}$ based on variables of $\mathrm{Q}$ and $\mathrm{S}$

It is found on the scatterplot that the correlation of $\mathrm{Q}$ and $\mathrm{S}$ has a positive one-way value and indicated that it has a good positive correlation. But there are three dots on the left, it is shown that the respondents answer the questions on the questionnaires inappropriate, and two dots in the middle, shown that two respondents answer the positive questions with negative 
answers. And the rest of the answers are appropriate answers. So that the correlation of Q and $\mathrm{S}$ about the impact of freedom of expression on social media is accepted.

\subsection{Discussion}

A basic understanding of freedom of expression is the ability to express themselves without government interference, or law unless there is a direct and abusive expression that threatens another person or group[11]; [7]. It prohibits the state or other people in society from censorship that restricted for an only very serious reason [11]. The right to express one's ideas and opinions freely can be in the form of speech, writing and other forms of communication, without causing damage to the character, or reputation of others with false or misleading statements. Unless a speech that aims to lead to some mischievous action in circumstances which are conducive to the taking action [12]. In term of understanding freedom of expression on social media, most teenagers follow the rules and regulations. In the interview with some of them, they are not willing to cause a problem even though there are a move in circulation around them that makes them want to comments. As the problem in Tempo.co on January 2, 2013, it had been indicated that the misused of social media and misused freedom of expression that some of the teenagers in the school had done to her. Some of the teenagers should read and understand the rules and regulation of social media and understand clearly about freedom of expression,the fact that freedom of expression is to protect actions, the words that are owned so that they can be immune from the limitation of other actions which are subject to the fact that they have adverse consequences and this is sufficiently sanctioned [1], [12], [13].

Social media is vital to freedom of expression which essential to share sources of information, a public sphere. With the growing commercialization and far-reaching media convergence in the wake of change of communication systems, social behavior is changed in functions as well as management practices. Public sphere and the context of freedom of expression have been changed [14]. As a platform, social media is used for learning and socialization. In the interview, teenagers mentioned that they use social media mostly for learning and finding the sources for learning and teenagers have changed the way they act and learn. They use social media to communicate and to find sources of learning. With the case above, some teenagers must learn about freedom of expression on social media and need to follow the rules and regulations of using social media. By having known about freedom of expression on social media, teenagers have more knowledge and skills in order to have digital communication in $21^{\text {st }}$-century communication.

\section{Conclusion}

Even though social media comes in various forms and structures and allows a better understanding of individuals, groups and online organizations in using social media. And teenagers who are interested mostly in using social media should be careful. Because it will promote the causes, engage the conversation that matter to them and others. Also, teenagers should understand that to give comments, sharing and to have a conversation on social media. The structure of social media can enable not only teenagers but also people to participate in a set of a target for what they want to be like.

Additionally, social media can help individuals, group or organization make the informed decision about an online conversation. This reflects the precise balance of the value of the expression in social life. It means teenagers should ensure equitable distribution of 
expression in the society whether they are compatible with the recognition of a certain special right. It is indeed a bit complicated that various part of freedom of expression on social media need to be reducible and the most important thing is to be responsible for a variety of cases that seems to be intuitively shape of violation of freedom of expression. Further, it may select a network type as the desired for the topic of discussion. With a goal in mind, the teenagers can create more to measure the difference between the topic of discussions, comments or sharing and the one that they engage to perform on a social media network.

Finally, by understanding freedom of expression on social media, teenagers will have strong knowledge and good skills to prepare themselves to the digital communication age.

Acknowledgments. The author would like to thank dean of Fakultas Sains dan Teknologi, Universitas Buddhi Dharma, Tangerang, Fakultas Humaniora, Universitas Guna Dharma, Fakultas Language and Art, Universitas Indraprasta who have supported the authors to do this research. And Also, the author would like to thank Ikatan Dosen Republik Indonesia (IDRI) that has sponsored this event.

\section{References}

[1] A. M. Kaplan and M. Haenlein, "Users of the world, unite! The challenges and opportunities of Social Media," Bus. Horiz., vol. 53, no. 1, pp. 59-68, Jan. 2010.

[2] David L. Hudson, "Student Expression in the Age of Columbine: Securing Safety and Protecting First Amendment Rights," First Amend. Cent., vol. 6, no. 2, 2005.

[3] Wilga Secsio Ratsja Putri, R. N. Nurwati, and M. Budiarti, "Pengaruh Media Sosial Bagi Remaja," Prosiding KS: Riset \& PKM, 2016. .

[4] E. Triastuti, D. Adrianto, and A. Nurul, Kajian Dampak Penggunaan Media Sosial Bagi Anak dan Remaja. Depok: Puskakom UI, 2017.

[5] I. Richardson, "Social media for children and teenagers," 2018. .

[6] L. Townsend and C. Wallace, Social Media Research: A Guide to Ethics. Aberdeen, Aberdeen, Scotland: University of Aberdeen, 2010.

[7] A.Stewart, "Social Media and the Human Right to Freedom of Expression." 2016.

[8] G. W. Reynolds, Ethics in Information and Technology, 5th editio. Boston, MA: Cengage Learning, 2015.

[9] H. G. Axberger, "Freedom of Expression as a Public Service," in Blurring the lines: Market-driven and democracy-driven freedom of expression, M. Edström and A. T. Kenyon, Eds. Sweden: Nordicom University of Gothenburg, 2016, pp. 51-60.

[10] Karman, "Media Sosial: Antara Kebebasan Dan Eksploitasi," J. Stud. Komun. dan Media, vol. 8, no. 1, pp. 75-88, 2014.

[11] D. McGoldrick, "The Limits of Freedom of Expression on Facebook and Social Networking Sites: A UK Perspective," Hum. Rights Law Rev., vol. 13, no. 1, pp. 125151, Mar. 2013.

[12] T. M. Scanlon, "Freedom of expression and categories of expression," in The Difficulty of Tolerance, Cambridge: Cambridge University Press, 2007, pp. 84-112.

[13] M. P. Granger and O. Salat, Barrier Towards EU Citizenship Case Study (II): On Freedom of Expression in the Context of. Media, Madrid, Spain: Beucitizen, 2016.

[14] U.Carlsson, "Opening speech: Freedom of Expression in Transition. A Media Perspective," in Blurring the lines: Market-driven and democracy-driven freedom of expression, M. Edström and A. T. Kenyon, Eds. Gothenburg, Sweden: Nordicom 
University of Gothenburg, 2016, pp. 19-29. 